\title{
The Most Excellent Princes: Geoffrey of Monmouth and Medieval Welsh Historical Writing
}

\author{
Owain Wyn Jones
}

\begin{abstract}
A late 14th-century manuscript of Brut y Brenhinedd ("History of the Kings"), the Welsh translation of Geoffrey of Monmouth's De gestis Britonum, closes with a colophon by the scribe, Hywel Fychan,
\end{abstract}

\begin{abstract}
Hywel Fychan ap Hywel Goch of Buellt wrote this entire manuscript lest word or letter be forgotten, on the request and command of his master, none other than Hopcyn son of Tomos son of Einion ... And in their opinion, the least praiseworthy of those princes who ruled above are Gwrtheyrn and Medrawd [Vortigern and Mordred]. Since because of their treachery and deceit and counsel the most excellent princes were ruined, men whose descendants have lamented after them from that day until this. Those who suffer pain and subjection and exile in their native land. ${ }^{1}$
\end{abstract}

These words indicate the central role Geoffrey's narrative had by this point assumed not only in vernacular historical writing, but also in the way the Welsh conceived of their past and explained their present. Hywel was writing around the time of the outbreak of Owain Glyn Dŵr's revolt, and the ethnic and colonial grievances which led to that war are here articulated with reference to the coming of the Saxons and the fall of Arthur. ${ }^{2}$ During the revolt itself, Glyn D̂̂r's supporters justified his cause with reference to the Galfridian past, for

1 Philadelphia, Library Company of Philadelphia, 868o.O, at fol. 68v: "Y llyuyr h6nn a yscriuenn6ys Howel Vychan uab Howel Goch o Uuellt yn ll6yr onys g6naeth agkof a da6 geir neu lythyren, o arch a gorchymun y vaester, nyt amgen Hopkyn uab Thomas uab Eina6n ... Ac o'e barn 6ynt, anuolyannussaf o'r ty6yssogyon uchot y llywyassant, G6rtheyrn a Medra6t. Kanys oc eu brat 6ynt a'e t6yll ac eu kyghor uynt y distry6yt y tywyssogyon arbennickaf, yr hynn a g6yna6d eu hetiuedyon g6edy 6ynt yr hynny hyd hedi6. Y rei yssyd yn godef poen ac achenoctit ac alltuded yn eu ganedic dayar." My transcription and translation.

2 For Hopcyn and the manuscript, see B.F. Roberts, "Un o Lawysgrifau Hopcyn ap Tomas o Ynys Dawe" [One of the manuscripts of Hopcyn ap Tomas of Ynys Dawe], Bв 2 22 (1966-68), 223-28, and more recently B. Guy, "A Welsh Manuscript in America: Library Company of Philadelphia, 868o.O", National Library of Wales Journal 36 (2014), 1-26. 
example, in Glyn Dîr's letter to the king of Scotland, where the opposition of both the Scots and the Welsh to the English was contextualized as deriving from the Saxon invasion. Here, Glyn Dŵr as Prince of Wales was portrayed as the heir of Camber and Cadwaladr, with Robert of Scotland depicted as the descendant of Albanactus. ${ }^{3}$ On campaign in 1403, Glyn Dîr himself consulted with Hopcyn ap Tomos, Hywel Fychan's patron and the owner of the manuscript quoted above, because of his reputation as a master of brut, that is, history and prophecy. ${ }^{4}$ More than 100 years before, in the last days of an independent Gwynedd, Galfridian history was also put to political use in the reply of Prince Llywelyn ap Gruffudd's royal counselors to the peace proposals of Archbishop Peckham, which justified Llywelyn's position, and that of Wales in relation to the English king, with reference to the division of Britain between Locrinus, Camber, and Albanactus after the death of Brutus in Geoffrey's history, maintaining that Snowdonia had belonged to the prince of Wales since the time of Brutus. ${ }^{5}$ Contemporary English chronicles also claim that Llywelyn's fellow countrymen spurred him on with Merlin's prophecies and predictions that he would wear the diadem of Brutus. ${ }^{6}$

These are some of the clearest examples of the use of Geoffrey's history for political ends in medieval Wales, and indicate the pervasive influence of Geoffrey's work on Welsh historical culture and on ideas of Welsh nationality. Between the late 12th and the 14th century his work had become accepted as the foundational narrative of Welsh history, and it is this process which is the primary concern of this chapter. Geoffrey described himself as a Briton and a man of Monmouth, and he can be considered a Welsh author in the sense that his origins lay in Wales and his historical writing drew on and developed pre-existing themes in Welsh ideas of the past. The central themes of Geoffrey's history were not his own invention, and are clearly seen in one of his

3 Adam Usk, Chronicle, ed. C. Given-Wilson, The Chronicle of Adam Usk, Oxford, 1997, pp. ${ }^{148-50 .}$

4 R.R. Davies, The Revolt of Owain Glyn Dîr, Oxford, 1995, pp. 159-6o; G.J. Williams, Traddodiad Llenyddol Morgannwg [The literary tradition of Morgannwg], Cardiff, 1948, p. 11; Original Letters Illustrative of English History, ed. H.F. Ellis, second series, 4 vols., London, 1827, vol. 1, pp. 21-23.

5 The Acts of Welsh Rulers, 1120-1283, ed. H. Pryce, Cardiff, 2005, no. 431; J. Beverley Smith, Llywelyn ap Gruffudd, Prince of Wales, Cardiff, 1998, pp. 326, 542-45; id., Yr Ymwybod â Hanes yng Nghymru yn yr Oesoedd Canol: Darlith Agoriadol/The Sense of History in Medieval Wales: an Inaugural Lecture, Aberystwyth, 1989, pp. 14-15.

6 Flores Historiarum, ed. H.R. Luard, 3 vols., London, 189o, vol. 3, p. 57; "Annales Londonienses", ed. W. Stubbs, Chronicles of the Reigns of Edward I and Edward II, 2 vols., London, 1882-83, vol. 1, pp. 1-251, at p. 9 o. 
most important sources, Historia Brittonum. ${ }^{7}$ The importance of these themes, such as the relationship between the Britons and the Romans, the status of the Britons as the rightful owners of the island of Britain and their loss of dominance through sin, the unity of the island of Britain, and the central role of figures such as Vortigern and Arthur, were important in earlier Welsh writing. Geoffrey, however, drew these together into an epic account of the past and the future, and the popularity and sheer coherence of his work had a profound effect in giving permanent shape to these earlier ideas. ${ }^{8}$

Geoffrey wrote in a period when political developments across Britain required urgent redefinitions of Welsh identities, and his history, both in its Latin form and in translation, became a point of reference in defining the Welsh, both in their own eyes and through those of their enemies. The history influenced the chronicles compiled at monasteries in Wales, particularly the Cistercian daughter houses of Whitland, which formed a network across native Wales. The influence of his writing can be detected in the poetry of the Gogynfeirdd, "not-so-early poets", the court poets of the Welsh princes, from the turn of the 13th century, and is also apparent in definitive texts of native Welsh historical lore such as Trioedd Ynys Prydein ("Triads of the Island of Britain"), genealogical collections, and prose tales. It was the subject of editing and interpretation in Latin by Madog of Edeirnion, as well as being translated and reformulated in Welsh numerous times. By defining so coherently the scope of pre-medieval Welsh history, as well as forcing reaction and redefinition of existing ideas and texts, it also exerted a fossilizing influence on ideas of the Welsh past. The definitive combination of Ystorya Dared, Bruty Brenhinedd, and Brut y Tywysogyon ("History of the Princes"), in which the Welsh translation of Geoffrey's history assumes a central place, became the most important account of the Welsh past and left little room for any re-interpretation of a national narrative in the early modern period. ${ }^{9}$

7 See Ben Guy's chapter in this volume.

8 B.F. Roberts, "Sylwadau ar Sieffre o Fynwy a'r Historia Regum Britanniae" [Remarks on Geoffrey of Monmouth and the Historia Regum Britanniae], Llên Cymru 12 (1972-73), 127-45, at pp. 139-45. Roberts notes three pervasive themes indicative of Welsh historical writing that Geoffrey correctly expresses: the unity of the island of Britain expressed through one crown; an awareness of the fall and loss of this lordship; and the hope for its restoration promised through prophecy. Roberts also argues for the centrality of the theme of the relationship between the Britons and the Romans, as well as the importance of considering the prophesied restoration of British overlordship over the island in any assessment of Geoffrey's national sympathies. See also B.F. Roberts, "Geoffrey of Monmouth and Welsh Historical Tradition", Nottingham Medieval Studies 20 (1976), 29-40.

9 Ystorya Dared is a Welsh translation of the Trojan history of pseudo-Dares, discussed most fully by B.G. Owens, "Y Fersiynau Cymraeg o Dares Phrygius (Ystorya Dared): eu Tarddiad, eu 
This chapter discusses Geoffrey's influence on Wales, but in doing so, consideration must be given to Geoffrey's own relationship with the country. Another chapter in this volume has discussed Geoffrey's use of Welsh sources in detail, but it will be necessary to briefly reconsider these issues in order to establish Geoffrey in his context. ${ }^{10}$ It is clear that Geoffrey cannot be placed in the main stream of existing Welsh historical thought, just as he was, in certain ways, not in the main stream of Anglo-Norman historiography. ${ }^{11}$ Nevertheless, he understood and manipulated the essential themes of existing Welsh historical texts, and was well acquainted with them.

The known sources of Geoffrey's work include some of the most important early medieval accounts of the British past: Gildas's The Ruin of Britain, the Historia Brittonum of Nennius, and Bede's Ecclesiastical History. These, along with his mentions of William of Malmesbury and Henry of Huntingdon in his history's final chapter, indicate clearly that Geoffrey was writing in an Insular Latinate tradition, and one which was revivified and redefined in the decades after the Norman Conquest. ${ }^{12}$ He used and expanded upon these earlier accounts, but his work was also one of subversion and distortion. He was deliberately superseding and undermining the work of Bede and his Anglo-Norman successors, putting his Britons at the forefront of a narrative that went far beyond these Anglocentric accounts in its chronological scope. ${ }^{13}$

Nodweddion a'u Cydberthynas" [The Welsh versions of Dares Phrygius (Ystorya Dared): their origin, their attributes, and their interrelationships], unpublished MA thesis, University of Wales, 1951, and most recently by H. Fulton, "Troy Story: The Medieval Welsh Ystorya Dared and the Brut Tradition of British History", in J. Dresvina and N. Sparks (eds.), The Medieval Chronicle VII, Amsterdam, 2011, pp. 137-50. Brut y Brenhinedd is the collective term used for Welsh translations of the $D G B$, and Brut $y$ Tywysogyon is a family of Welsh vernacular chronicles covering the history of Wales from the late 7 th century to the late 13th. These last two are discussed in more detail below.

10 See Ben Guy's chapter in this volume.

11 See Georgia Henley and Rebecca Thomas's chapters in this volume.

12 For the impact of the conquest on historical writing in England, see R.W. Southern, "Aspects of the European Tradition of Historical Writing, 4: The Sense of the Past", Transactions of the Royal Historical Society, fifth series, 23 (1973), 243-63, at pp. 246-56, although Southern maintains a distinction between this historical revival and Geoffrey: id., "Aspects of the European Tradition of Historical Writing, 1: The Classical Tradition from Einhard to Geoffrey of Monmouth", Transactions of the Royal Historical Society, fifth series, 20 (1970), 173-96, at pp. 193-95.

13 R.W. Leckie, Jr., The Passage of Dominion: Geoffrey of Monmouth and the Periodization of Insular History in the Twelfth Century, Toronto, 1981, pp. 11-21, 54, 57, 66-68; K. Jankulak, Geoffrey of Monmouth, Cardiff, 2010, p. 20. 
In so doing it can be argued that he had a comparable agenda to one of his main sources, Nennius's Historia Brittonum. Geoffrey transformed elements of the more patchwork Historia Brittonum into some of the key set-pieces of his grand narrative history, and the two texts are very different. Nevertheless both are pseudo-histories with similar preoccupations, with Historia Brittonum reading "almost like a reply to Bede". ${ }^{14}$ One of its preoccupations was to present an alternative view of the Britons to the unflattering one provided by Bede, and to establish them as a providential people. ${ }^{15}$ For example, Nennius's mention of Rhun ab Urien's conversion of Edwin of Northumbria specifically contradicts Bede's account of the conversion of this first Christian king of Northumbria by the Roman missionary Paulinus, and more broadly contradicts Bede's claim that the Britons never preached the word of God to the English. ${ }^{16}$

Similarly, Geoffrey pulls the rug from under Bede and his successors in innumerable ways, most notably in his portrayal of the maintenance of British rule over Britain between the Romans and the $7_{\text {th }}$ century. In undermining and challenging the Bedan account of British history, Geoffrey was writing within a Welsh Latinate tradition. While the $D G B$ clearly fits into the context of 12th-century Anglo-Norman historical writing, and is intended for an Anglo-Norman audience, it also fits into the Welsh tradition of its immediate sources. It took from Historia Brittonum the most essential elements of its narrative, including the Trojan origins of the Britons, but they were transformed and developed by Geoffrey.

While his direct links with earlier, well-attested Latinate sources are reasonably straightforward, the same cannot be said for Geoffrey's dependence on Welsh vernacular sources, which indicate a process of independent development, imitation, and cross-fertilization appreciable from a distance, but rarely traceable in detail. Although there were certainly vernacular manuscripts long before this point, the earliest surviving manuscripts postdate the publication of the $D G B$ by about a century, and indeed are later than the time at which Geoffrey's work is estimated to have been translated into Welsh. ${ }^{17}$ It is therefore only with some difficulty that we can appreciate the form of vernacular ideas of the Welsh past before Geoffrey's influence was felt. Certain texts are certainly older than Geoffrey, some show no influence from his work, and others

\footnotetext{
14 P. Sims-Williams, "Some Functions of Origin Stories in Early Medieval Wales", in T. Nyberg (ed.), History and Heroic Tale: a Symposium, Odense, 1985, pp. 97-131, at p. 117.

15 N.J. Higham, King Arthur: Myth-Making and History, London, 2002, pp. 116-66.

16 Bede, Ecclesiastical History i.22, ii.9, ii.13, ed. and trans. B. Colgrave and R.A.B. Mynors, Bede's Ecclesiastical History of the English People, Oxford, 1969, pp. 66-68, 162-66, 182-86; Historia Brittonum, ed. Faral, $L L A$, pp. 2-62, at pp. 40, 43, 46.

17 D. Huws, Medieval Welsh Manuscripts, Aberystwyth, 200o, pp. 36-41.
} 
in their different and developing versions betray the gradual intensification of the hold of Geoffrey's work on the Welsh historical imagination.

Geoffrey claimed a debt to vernacular writing, as is clear from his references to the liber vetustissimus, "very ancient book". ${ }^{18}$ This claim is basically spurious, but it is indicative of a broader truth, as suggested by parallels between his work and vernacular texts. The small number of inconsistencies between it and independent Welsh accounts of the past, often noted or subtly avoided by Welsh scribes and translators, indicates the broader consistency between Galfridian history and earlier Welsh ideas. Some aspects of the $D G B$ are appreciable in Historia Brittonum, but its wider themes and many of the historical and pseudo-historical characters are also apparent in vernacular Welsh texts. The most comprehensive of these in historical terms is Trioedd Ynys Prydein, a collection of historical and legendary triads which represent one of the key authorities on native Welsh history available to medieval poets. ${ }^{19}$ The date of composition of these triads is difficult to determine, since information in triadic form is likely to have circulated before the collection of the Trioedd in their current form. The earliest surviving version of Trioedd Ynys Prydein cannot be earlier than the early 12 th century, and was perhaps compiled around the middle of that century. ${ }^{20}$

The compilation of the earliest version of Trioedd Ynys Prydein may therefore have been roughly contemporary with Geoffrey's writing, although its method of codifying the past is strikingly different. A triad, at its simplest, is a list of three items grouped thematically. In Wales, triads were used for legal codes and poetic technique as well as for cataloguing legendary figures. The legendary triads in Trioedd Ynys Prydein usually consist of a title, such as "The Three Battle-Rulers of the Island of Britain", and then a list of three figures or events. Some triads are much fuller, relating many details of the stories connected with these figures, but for the most part the references are either to characters known from elsewhere in medieval Welsh literature and history, or to figures whose stories have not survived.

$18 \quad D G B$, Prologus 2.10.

19 Trioedd Ynys Prydein: The Triads of the Island of Britain, ed. and trans. R. Bromwich, 4th ed., Cardiff, 2014.

20 The earliest version occurs in Aberystwyth, National Library of Wales, Peniarth 16.iv (s. xiii ${ }^{2}$ ). The rationale for this dating includes references to the Trioedd by poets such as Cynddelw (fl.1155-95); an indication of interest in the earliest version of Trioedd Ynys Prydein in the controversy over St Davids' archiepiscopal status; and the occurrence in this same version of references to Gilbert mab Catgyffro, probably Gilbert fitz Richard de Clare (d. 1114), and Alan Fergant (d. 1119). Huws, Medieval Welsh Manuscripts, p. 6o; Trioedd, ed. and trans. Bromwich, pp. xvi, lxxxvi, xc-xciii, 1, 46, 66. 
The characters and subject-matter of the earliest version of Trioedd Ynys Prydein show a considerable overlap with Geoffrey but also some important differences. For instance, the first triad in the collection speaks of the Teir Lleithicl6yth, "three tribal thrones", of the island of Britain, echoing Geoffrey's tripartite division of the island. But although Arthur is thrice named in this triad, the divisions of the island do not reflect Geoffrey's history and the details of the triad are clearly independent of his work. ${ }^{21}$ In some few instances, such as the idea of Edwin of Northumbria's fosterage in Gwynedd and the exile of Cadwallon in Ireland, it seems that Geoffrey was independently drawing on historical information which was also contained in the Trioedd. ${ }^{22}$ It is also apparent that in later versions of the Trioedd there is an increasing influence from Geoffrey's work. For example, the first triad in the collection names Arthur's chief courts as Mynyw (St Davids), Celliwig, and Pen Rhionydd, but in later versions the first of these is changed to Caerleon in deference to Geoffrey. ${ }^{23}$

Rachel Bromwich's discussion and edition of the Trioedd and their use by court poets reveals a busy and engaging historical tradition that was informed of Geoffrey's work, but by no means dominated by it. She also argues that Trioedd Ynys Prydein represented a "safeguarded bardic learning" to which Geoffrey did not have access. ${ }^{24}$ This reveals something of the ambiguity of Geoffrey's place in Welsh tradition - he is in some ways both an outsider and an insider, the writer of a confected history which confounded and then convinced not only his Anglo-Norman audience, but also the native Welsh intellectual elite. This elite can be conceived of as primarily dependent on the Welsh princely courts, and formed of cyfarwyddiaid, "court poets and storytellers", whose works, though essentially oral and performative, were increasingly recorded in writing from the mid-13th century onwards and defined contemporary ideas of the Welsh past. ${ }^{25}$

The Trioedd themselves also suggest a reason for both the popularity and the novelty of Geoffrey's narrative in Wales, as well as the dominant position his account achieved. The Trioedd are a very different way of recording and

21 Trioedd, ed. and trans. Bromwich, pp. 1-4.

22 Trioedd, ed. and trans. Bromwich, p. lxxx.

23 For a discussion of the different versions of the Trioedd with particular attention given to the importance of Arthur and the increasing influence of Geoffrey, see R. Shercliff, "Arthur in Trioedd Ynys Prydain", in C. Lloyd-Morgan and E. Poppe (eds.), Arthur in the Celtic Languages: The Arthurian Legend in Celtic Literatures and Traditions (Arthurian Literature in the Middle Ages, 9), Cardiff, 2019, 173-86.

24 Trioedd, ed. and trans. Bromwich, p. lxxx.

25 Sims-Williams, "Some Functions of Origin Stories", pp. 101-02. 
understanding the past, in that they do not present a coherent sequential narrative, but rather group events by association - the past is catalogued in terms of the similarity of one event to the other, rather than the chronological relationship between events. Geoffrey, however, presented a grand and compelling chronological narrative into which it was possible to fit earlier traditions, but in doing so changed the framework of those traditions - in later versions of the Trioedd, the formula tri $x$ Ynys Prydein, "the three $\mathbf{x}$ of the Island of Britain", is replaced by tri $x$ Llys Arthur, "the three $\mathbf{x}$ of Arthur's Court". 26

There are other indications of Welsh ideas of the past which were close to Geoffrey's version, but independent of it. In the case of the Welsh laws, Cyfraith Hywel ("The Law of Hywel"), details relating to the establishment of laws, the setting of measurements, and the building of roads by Dyfnwal Moelmut correspond in some ways with Geoffrey's own account of Dunuallo Molmutius. Although the laws in their current form post-date Geoffrey's work, there are differences between the two accounts which suggest that the account of Dyfnwal in Cyfraith Hywel is not derived solely from Geoffrey, but may draw on an independent account which also saw Dyfnwal as a law-giver with an interest in roads. ${ }^{27}$ We see here then an indication that Geoffrey was able to draw on some older ideas about the British past and give them a concrete and coherent, though changed form in his history. But some texts indicate considerable difference, such as Enweu Ynys Prydein ("The Names of the Island of Britain"), which first occurs in 14th-century manuscripts. This short text embodies ideas of the Welsh past independent of Geoffrey's work, to the extent that it contains a different account of the settlement and conquest of Britain. It has been said to represent "a pseudo-learned Welsh tradition which is long anterior to the time of Geoffrey of Monmouth".28 Its antiquity is difficult to establish, though its difference cannot be doubted.

The themes and preoccupations of Geoffrey's work were also articulated in contemporary Welsh Latinate chronicling. I have elsewhere suggested parallels

26 While the compilation of the earliest version of Trioedd Ynys Prydein is perhaps roughly contemporary with Geoffrey, the antiquity of the triadic form as a way of cataloguing history is apparent from earlier sources such as the Gododdin: Trioedd, ed. and trans. Bromwich, pp. liii-xcix.

27 Llyfr Colan:y Gyfraith Gymraegyn ôl Hanner Cyntaf Llawysgrif Peniarth 30 [The Llyfr Colan: Welsh law according to the first half of manuscript Peniarth 30 ], ed. D. Jenkins, Cardiff, 1963, pp. 38-39, 159; The Laws of Hywel Dda: Law Texts from Medieval Wales, ed. D. Jenkins, Llandysul, 1986, pp. 120, 268; $D G B$, ii.34.305-37; Jankulak, Geoffrey of Monmouth, pp. 16-17; M.E. Owen, "Royal Propaganda: Stories from the Law-Texts", in T.M. Charles-Edwards, M.E. Owen, and P. Russell (eds.), The Welsh King and His Court, Cardiff, 200o, pp. 224-54, at pp. 229-32, 250-51.

28 Trioedd, ed. and trans. Bromwich, pp. c-civ, 246-55. 
between Geoffrey's approach to historical writing and that of the author of the "Llanbadarn History", a section of the chronicle Brut y Tywysogyon probably written sometime before $1127 .{ }^{29}$ Specifically, the theme of a loss of kingship among the Welsh through the judgement of God and the use of rhetorical speeches to expound this theme are present in both texts. The author, though undoubtedly Welsh, also shows a political ambiguity toward his countrymen reminiscent of Geoffrey. Geoffrey's connections with men such as Caradog of Llancarfan, his contemporary, and Rhygyfarch ap Sulien from the generation before, place him in the same cultural milieu as the author of this "Llanbadarn History", and their similarity in historiographical ideas is a further illustration of this. ${ }^{30}$

Geoffrey's use of the genealogical corpus, as discussed in another chapter, reveals a keen historical understanding combined with the cavalier attitude which is so characteristic of his use of sources. His plundering of the Harleian genealogies for the list of attendees at Arthur's court could be characterized as showing scant regard for Welsh historical convention, but it is entirely in keeping with the approach of vernacular texts. The prose tale Culhwch and Olwen cannot be proven to predate the $D G B$, but it is certainly independent of its influence in terms of content. It contains a similar, though more extensive, list which shows a comparable willingness to plunder disparate source material for the purpose of filling Arthur's court, and a comparable disregard for the earlier historical context of these names. ${ }^{31}$

Links between Geoffrey's work and earlier vernacular poetry can be established with some confidence. As already noted in a previous chapter, he shows a clear acquaintance with the 1oth-century prophetic poem Armes Prydein $V a w r$, and the $V M$ shows a wider familiarity with poetry surrounding Myrddin. The matter of the $V M$ 's relationship with Welsh vernacular texts encapsulates many of the issues which confront us when trying to disentangle Geoffrey's Welsh sources from those influenced by him. The Welsh literary material relating to Myrddin, most notably the poems contained in Llyfr Du Caerfyrddin ("The Black Book of Carmarthen"), present a picture which is comparable to that of

29 O.W. Jones, "Brut y Tywysogion: the History of the Princes and Twelfth-Century Cambro-Latin Historical Writing”, Haskins Society Journal 26 (2014), 209-27, at pp. 222-27.

30 Geoffrey was probably familiar with Rhygyfarch's Life of St David. See N. Wright, "Geoffrey of Monmouth and Gildas Revisited", $A L 5$ (1985), 155-63, at p. 156; see also Ben Guy's chapter in this volume, p. 59 .

31 Culhwch and Olwen, ed. R. Bromwich and D.S. Evans, Culhwch ac Olwen: an Edition and Study of the Oldest Arthurian Tale, Cardiff, 1992, pp. 7-15, 68-112. 
the $V M .^{32}$ The classic view of the relationship of these texts is A.O.H. Jarman's, who argued that after the publication of the $D G B$, Geoffrey became acquainted with earlier Welsh material which placed Myrddin in the context of the battle of Arfderydd, known from earlier Cambro-Latin annals and the Trioedd Ynys Prydein. He adapted this in his later work, the VM, which took many of these themes and developed them into polished, literary, and Latinate form. ${ }^{33}$ An issue here is again the later date of our earliest versions of these Welsh texts, which all post-date Geoffrey: Llyfr Du Caerfyrddin is a manuscript of c.125o, therefore roughly contemporary with our earliest manuscripts containing vernacular translations of the $D G B$. This has led to more recent reassessments which suggest that the Welsh material betrays considerable influence from Geoffrey's own work rather than vice-versa. ${ }^{34}$

What is undoubtedly true is that the exact relationship between these Welsh sources and Geoffrey's work could, like the $V M$ itself, benefit from considerable further study. ${ }^{35}$ The relatively limited distribution of the $V M$ in its Latin form, and the nature of the Welsh references to Myrddin, leads the current author to suspect that Geoffrey did draw to a considerable degree on earlier Welsh sources in creating the Myrddin of the $V M .^{36}$ The parallels between the Welsh and Galfridian material are rarely exact, particularly compared to the relatively faithful translations of the $D G B$, and this in itself suggests a process of reformulation and creative recasting on Geoffrey's part of a fairly wide range

32 Llyfr Du Caerfyrddin: gyda Rhagymadrodd, Nodiadau Testunol, a Geirfa [The Black Book of Carmarthen: with introduction, textual notes, and vocabulary], ed. A.O.H. Jarman, Cardiff, 1982, pp. 1-2, 26-35; an additional relevant poem is Cyfoesi Myrddin a Gwenddydd ei Chwaer ("The Prophecy of Myrddin and Gwenddydd his Sister"), which first occurs in a manuscript of $c .133$; see M.B. Jenkins, "Aspects of the Welsh Prophetic Verse Tradition: Incorporating Textual Studies of the Poetry from 'Llyfr Coch Hergest' (Oxford, Jesus College, MS cxi) and 'Y Cwta Cyfarwydd' (Aberystwyth, National Library of Wales, MS Peniarth 5o)", unpublished PhD thesis, University of Cambridge, 1990, pp. 80-83. English translations of these items are in J.K. Bollard, "Myrddin in the Early Welsh Tradition", in P. Goodrich (ed.), The Romance of Merlin: An Anthology, New York, 199o, pp. 13-54; VM.

33 A.O.H. Jarman, "The Welsh Myrddin Poems", in R.S. Loomis (ed.), Arthurian Literature in the Middle Ages, Oxford, 1959, pp. 20-30; id., The Legend of Merlin, Cardiff, 196o; id., "The Merlin Legend and the Welsh Tradition of Prophecy", in R. Bromwich, A.O.H. Jarman, and B.F. Roberts (eds.), The Arthur of the Welsh: The Arthurian Legend in Medieval Welsh Literature (Arthurian Literature in the Middle Ages, 1), Cardiff, 1991, 117-45. Jarman's views are well summarized in O.J. Padel, "Geoffrey of Monmouth and the Development of the Merlin Legend”, cMcs 51 (2006), 37-65, at pp. 37-39.

34 Padel, "Geoffrey of Monmouth and the Development of the Merlin Legend".

35 Initial steps are made by Ben Guy elsewhere in this volume.

36 This is broadly the conclusion of Nikolai Tolstoy's reassessment in light of Padel's argument, "Geoffrey of Monmouth and the Merlin Legend", $A L 25$ (2008), 1-42, and of Ben Guy in this volume. For the manuscripts, see $V M$, pp. 43-45. 
of Welsh texts, a process already familiar from the $D G B$. As noted by Ben Guy elsewhere in this volume, the closest direct parallels between Geoffrey's work and definitely earlier Welsh poetry are between the VM and Armes Prydein. Overall, the $V M$ suggests Geoffrey's familiarity with and creative recasting of vernacular Welsh texts.

Whereas Geoffrey owed a debt to Welsh poetry himself, it is also possible, through the easily-datable corpus of court poetry from the early 12 th century onwards, to appreciate the growing influence of his work on the bards' own ideas of the past. The poetry of the Gogynfeirdd is preserved relatively consistently from the early 12 th century to the late $13^{\text {th }}$, and some of the earliest poems in this corpus demonstrate Geoffrey's fundamental agreement with earlier Welsh tradition. The anonymous praise poem to Hywel ap Goronwy, a southern Welsh ruler who died in 1106, refers to the tripartite division of Britain, suggests the importance of the crown of London, and mentions a figure used by Geoffrey, Urien (Urianus). ${ }^{37}$ Poems such as this demonstrate thematic closeness but not direct influence.

The poetry of Cynddelw (active 1155-95), one of the greatest of the court poets in both the quality and volume of his poetry, shows little indication of Galfridian influence. In general, Cynddelw's poetry is a repository of antiquarian and traditional references, sometimes to figures which are no more than names in our surviving material. ${ }^{38}$ His few Arthurian references indicate a familiarity with Culhwch and Olwen, a text which shows no Galfridian influence. ${ }^{39}$ Later poets, however, reveal the increasing influence of Geoffrey, perhaps through the vernacular translations of his work. Whereas Cynddelw only mentions Arthur twice, Llywarch ap Llywelyn (active 1174/75-1220) mentions

37 "Mawl Hywel ap Goronwy" [In praise of Hywel ap Goronwy], ed. R.G. Gruffydd, Gwaith Meilyr Brydydd a'i Ddisgynyddion [The work of Meilyr Brydydd and his descendants] (Cyfres Beirdd y Tywysogion, 1), ed. J.E.C. Williams, P. Lynch, and R.G. Gruffydd, Cardiff, 1994, pp. 1-21, ll. 20, 36, 4 o.

38 Cynddelw Brydydd Mawr, Opus, ed. N.A. Jones and A.P. Owen, Gwaith Cynddelw Brydydd Mawr I-II [The work of Cynddelw Brydydd Mawr I-II] (Cyfres Beirdd y Tywysogion, 3-4), 2 vols., Cardiff, 1991, vol. 1, pp. xli-xlii; A.P. Owen, "Cynddelw Brydydd Mawr a'i Grefft" [Cynddelw Brydydd Mawr and his craft], in M.E. Owen and B.F. Roberts (eds.), Beirdd a Thywysogion: Barddoniaeth Llys yng Nghymru, Iwerddon a'r Alban [Poets and princes: court poetry in Wales, Ireland, and Scotland], Cardiff, 1996, pp. 143-65, at pp. 151-53, 163 .

39 R. Bromwich, "Cyfeiriadau Traddodiadol a Chwedlonol y Gogynfeirdd" [Traditional and mythological references in the work of the Gogynfeirdd], in Owen and Roberts (eds.), Beirdd a Thywysogion, pp. 202-18, at pp. 202-03. For references to Arthur, the Twrch Trwyth, and Celli Wig, see Cynddelw Brydydd Mawr, Opus, ed. Jones and Owen, vol. 2, pp. 52, 79, 122, 148, 305, 320 . 
him six times in fewer poems. ${ }^{40}$ After the turn of the $13^{\text {th }}$ century, there are a much greater number of unambiguous references to characters derived from Geoffrey's work or influenced by it, and Llywarch ap Llywelyn stands on the brink of this change. ${ }^{41}$

The place of Geoffrey within earlier Welsh traditions of historical writing appears from the brief sketch above to be a relatively close one, although somewhat conflicted. He is consistent with the native Latinate tradition of historical writing apparent in one of his main sources, Historia Brittonum. He also has a close relationship with vernacular learning, although here he appears to be more of an outsider. If the earliest version of Trioedd Ynys Prydein was compiled around the mid-12th century, it demonstrates an impulse of historical collection, definition, and cataloguing which is strikingly similar to Geoffrey's in date and in its definition of the British past, although strikingly different in form and execution. The triads defined and codified the historical understanding of the court poets, but it was Geoffrey's history which was to have a more fundamental effect on Welsh ideas of the past.

The question of Geoffrey's ethnic origins is of course relevant when considering his place in an earlier Welsh historical tradition. It is discussed in more detail elsewhere in this volume, but the current author is largely in agreement with the editor's introduction. ${ }^{42}$ The longstanding idea that he was of Breton origin and that his sympathies lay with the Bretons rather than the Welsh, and more broadly with the Anglo-Norman elite, derive from a particular reading of his history. ${ }^{43}$ While the close of the $D G B$ could make depressing reading for a 12th-century Welshman, the larger prophetic structure of the work promises redemption and restoration. His ambiguity toward the Welsh of his own day is an attitude replicated by other Welsh authors of the same period. ${ }^{44}$ Welsh responses to his work, such as that of Madog of Edeirnion, chime better with John Gillingham's understanding of the history as a circular narrative promising redemption and restoration rather than Michael Faletra's more linear

40 Llywarch ap Llywelyn, Opus, ed. E.M. Jones and N.A. Jones, Gwaith Llywarch ap Llywelyn, 'Prydydd y Moch' [The work of Llywarch ap Llywelyn, 'Prydydd y Moch'] (Cyfres Beirdd y Tywysogion, 5), Cardiff, 1991, poem and line numbers: 5.12, 11.53, 12.8, 20.5, 23.64, 26.96. Bromwich, "Cyfeiriadau Traddodiadol", pp. 203-04.

42 See Joshua Byron Smith's Introduction, pp. 11-21.

43 Tatlock, $L H B$, pp. 414, 443.

44 For example, Rhygyfarch ap Sulien, whose Planctus denounces the servile and cowardly nature of the Welsh, and the author of the "Llanbadarn History": Rhygyfarch ap Sulien, Planctus, ed. M. Lapidge, “The Welsh-Latin Poetry of Sulien's Family”, Studia Celtica 8/9 (1973-74), 68-106, at pp. 88-93; O.W. Jones, “Bruty Tywysogion", pp. 224-26. 
reading, which emphasizes the fallen status of the Welsh as a legitimation of Anglo-Norman power. ${ }^{45}$

What must be emphasized is Geoffrey's articulation of an ancient British identity within which he places himself, both in ethnic terms and as a historian. He considered himself one of the Britons, and this, his command of the British language, and the authority of his ancient book established his credentials as their historian. He created a coherent and attractive past for the ancient inhabitants of Britain from whom the Welsh, Cornish, and Bretons claimed descent. He must in some sense be considered a Welsh author, not only in terms of his source material but also his origin in Monmouth, and his regard for Caerleon which shows his close connection with Gwent. Considering his interests and his origin in Welsh-speaking Gwent/Ergyng, it would be strange if he was not proficient in Welsh, and the available evidence suggests that he was. ${ }^{46} \mathrm{~A}$ feature of William fitz Osbern's conquest of Gwent was considerable institutional continuity on the part of the Welsh administrative class of the region. ${ }^{47} \mathrm{An}$ origin among such a Welsh family that benefitted from the Norman settlement in Wales could explain his sympathies just as well as a Breton descent, if indeed we need to invoke ethnic origins to explain political sympathies.

Geoffrey is a Welsh author in terms of his environment and source material, but there is a deliberate ambiguity in his identity. His description of the Britannici sermonis liber, "book in the British language", which came $e x$ Britannia, "from Britain", might be read as a source from Brittany, given the fact that he excludes the Welsh from the name "British" at the end of his history, and he consistently uses Kambria for Wales. However at all other points

45 I owe this insight to J. Byron Smith, "Feasting on the Past: Madog of Edeirnion's Version of the Historia Regum Britanniae", unpublished paper delivered at the Celtic Studies Association of North America annual meeting, St Francis Xavier University, Antigonish, Nova Scotia, 5 May 2016; J. Gillingham, "The Context and Purposes of Geoffrey of Monmouth's History of the Kings of Britain", Anglo-Norman Studies 13 (1990), 99-118 (repr. in id. (ed.), The English in the Twelfth Century: Imperialism, National Identity and Political Values, Woodbridge, 2000, pp. 19-39, at p. 31); M.A. Faletra, "Narrating the Matter of Britain: Geoffrey of Monmouth and the Norman Colonization of Wales", The Chaucer Review 35:1 (2000), 60-85, at pp. 67-69.

46 For Ergyng, which bordered Gwent and from which Monmouth was later separated, see B.G. Charles, "The Welsh, their Language and Place-Names in Archenfield and Oswestry", in Angles and Britons: O'Donnell Lectures, Cardiff, 1963, pp. 85-110; D.F. Evans, "Talm o Wentoedd: the Welsh Language and its Literature c.1070-c.1530", in R.A. Griffiths, T. Hopkins, and R. Howell (eds.), The Gwent County History vol. 2: the Age of the Marcher Lords, c.1070-1536, Cardiff, 2008, pp. 280-308, at pp. 281-83; T.D. Crawford, "On the Linguistic Competence of Geoffrey of Monmouth", Medium Avum 51 (1982), 152-62.

47 D. Crouch, "The Transformation of Medieval Gwent", in Griffiths, Hopkins, and Howell (eds.), Gwent County History, vol. 2, pp. 1-45, at pp. 4-6, 14-16. 
in the $D G B$ where Brittany is meant, it is qualified as Armoricana Britannia, "Armorican Britain", altera Britannia, "the other Britain", or minor Britannia, "lesser/smaller Britain". ${ }^{48}$ Had Geoffrey intended clarity, he would have made this clearer. Rather, Geoffrey is preserving and using the ambiguity of British terminology to establish his own intimate link to the ancient Britons he had gone to such lengths to define. The British language was that of the ancient Britons, and Britannia could be taken to mean Brittany or his island of Britain in the distant past.

Geoffrey's career was spent in England, probably as a secular canon of the collegiate church of St George in Oxford. ${ }^{49} \mathrm{He}$ had a close relationship with Welsh source material, but his apparent lack of knowledge of sources such as Welsh triads suggests that he was an outsider in relation to the vernacular tradition of the Welsh poets. The subversiveness of his history with regard to the conventional, Bedan narrative of English/British history also shows him as an outsider in an Anglo-Norman context. A process of mimicry and subversion is apparent in his work, both in relation to its undermining of accepted ideas of English/British history and its ambiguous relationship with existing Welsh ideas of the past. ${ }^{50}$ Geoffrey wrote in a tradition of Welsh pseudo-history and of Anglo-Norman historical writing, but as an outsider he redefined and transformed both..$^{51}$

Regardless of Geoffrey's strong links with Wales, the $D G B$ was a work written in England for Anglo-Norman patrons, and while the stir it caused on its publication is apparent from Henry of Huntingdon's response in 1139, we have

$48 \quad D G B$, v.84.311, v.84.325, v.86.354, v.88.411, vi.92.88, vi.96.235, vi.97.245, viii.120.63, xi.186.166, xi.194.332. In the last case, the meae Britanniae of King Salomon is distinguished from uestra Britanniae.

49 H.E. Salter, "Geoffrey of Monmouth and Oxford", EHR 34 (1919), 382-85.

$5^{\circ}$ I use the term mimicry as defined by Homi Bhabha. Mimicry entails the adoption of elements of the culture of the colonizers by the colonized in order to elevate their status in terms of the dominant, colonial discourse. There can be a subversive element to this mimicry, since the mimicry of the colonizer by the colonized changes and undermines those same elements of culture. The transformed image of the colonizer produced can be a threat to his authority. H.K. Bhabha, The Location of Culture, London and New York, 1994, pp. 85-92.

$5^{1} \quad$ For an excellent discussion of his relationship to both traditions, see Jankulak, Geoffrey of Monmouth, esp. pp. 22-28, 94. 
no indication of the nature of the initial response within Wales. ${ }^{52}$ Our main evidence for the initial reception of Geoffrey's work in Wales consists of early manuscripts, Gerald of Wales's response to Geoffrey's work, and the influence of the history on vernacular literature, more noticeable from around 1200. These will be taken in turn.

Few of the over 200 manuscripts of the $D G B$ can be said with certainty to be of Welsh provenance. Nevertheless one early manuscript of the 12th century with Welsh connections deserves consideration here. This is London, British Library, Royal 13 D. ii, which two ex libris inscriptions mark as having been the property of Margam Abbey in Glamorgan. It contains a copy of the vulgate version of the $D G B$ with the dedication to Robert of Gloucester, and can be dated to the late 12 th century. ${ }^{53}$

While there is no certainty that the manuscript was itself compiled at Margam, the connections of that monastery with Geoffrey's work suggest a possible route for the dissemination of Geoffrey's history in Wales. Robert was not only a dedicatee of Geoffrey's work but also the patron of Margam, and there is at least a possibility that the monastery acquired a copy from Robert himself: Walter Espec is known to have acquired a copy of the history from him before lending it to Ralf fitz Gilbert, husband of Gaimar's patroness, Lady Constance. ${ }^{54}$ The text of the $D G B$ in this manuscript is derived from one of the earliest available versions, and indicates that the monastery may have received a copy soon after publication. ${ }^{55}$ An interest in the work here is hardly surprising given that Margam itself is one of the few specific places in Wales named in Geoffrey's narrative. ${ }^{56}$ There are therefore reasons to suspect that this house may have played a role in the initial popularization of Geoffrey's work within Wales. This is interesting given that Margam can be seen as the Marcher Cistercian house with the strongest connections to native Wales, and the only

$5^{2}$ N. Wright, "The Place of Henry of Huntingdon's Epistola ad Warinum in the Text-History of Geoffrey of Monmouth's Historia regum Britanniae: a Preliminary Investigation", in G. Jondorf and D.N. Dumville (eds.), France and the British Isles in the Middle Ages and Renaissance: Essays by Members of Girton College, Cambridge, in Memory of Ruth Morgan, Woodbridge, 1991, 71-113.

53 Crick, $S C$, no. 112.

54 Geffrei Gaimar, Estoire des Engleis, ed. and trans. I. Short, Estoire des Engleis / History of the English, Oxford, 2009, p. 348; see also Jaakko Tahkokallio's chapter on early manuscript dissemination in this volume.

55 See Jaakko Tahkokallio's discussion of the manuscript elsewhere in this volume.

$56 \quad D G B$, ii.32.280-82. 
one where an attempt may have been made to found a daughter-house under native patronage, the failed foundation of Pendar. ${ }^{57}$

It is worth noting briefly that one of the figures linked with Pendar in charters, Meilyr awenydd, is associated with Geoffrey of Monmouth's work by Gerald of Wales. ${ }^{58}$ Gerald describes how the demons who tormented Meilyr, though put to flight when St John's gospel was placed on his lap, would return in full force and with greater severity when a copy of the "Historia Britonum" of Galfridus Arturus was put in its place. ${ }^{59}$ Although Gerald states that Meilyr was completely illiterate (which perhaps indicates his disapproval of Meilyr's activities rather than being strictly true), his account is good evidence for the spread of Geoffrey's influence in Wales by the later 12th century. Meilyr appears to have been an important intermediary between earlier Welsh religious traditions and the expanding, reforming monastic orders of the 12th century. This, at least, is the impression gained from his role in the Pendar charters together with Gerald's account. He appears as a key figure in the foundation of Pendar, receiving land from the native rulers of Morgannwg and confirmation from Earl William of Gloucester, and was an intermediary in the granting of lands from the native rulers of Morgannwg to Margam. ${ }^{60}$ Gerald's fantastical account relates that Meilyr spent time at St Davids and advised or criticized the abbots of Strata Marcella and Whitland. ${ }^{61}$

Gerald of Wales himself provides the clearest example of a Latinate response to Geoffrey's work in Wales. Gerald's knowledge of Geoffrey may have had more to do with his Norman background than his Welsh. The PM in particular was popular at the court of Henry II, although the Welsh background of this material was apparent to Gerald from his own experiences, particularly his

57 F.G. Cowley, The Monastic Order in South Wales 1066-1349 (Studies in Welsh History, 1), Cardiff, 1977, pp. 23-24.

58 Awenydd signifies "inspired person" or "soothsayer". Acts, ed. Pryce, no. 616.

59 Gerald of Wales, The Journey Through Wales i.5, ed. J.F. Dimock, Giraldi Cambrensis Opera, 8 vols., London, $1861-91$, vol. 6 , pp. $3^{-152}$, at pp. $57^{-5}$. The name Galfridus Arturus is also given to Geoffrey in contemporary charters, and both Robert of Torigni and Henry of Huntingdon refer to Geoffrey in this way. Bern, ed. Wright, p. ix.

6o Cartae et alia munimenta quae ad dominium de Glamorgancia pertinent, ed. G.T. Clark, 6 vols., 2nd ed., Cardiff, 1910, nos. Cxxx, CLXIX.

61 B. Golding, "Gerald of Wales and the Cistercians", Reading Medieval Studies 21 (1995), 5-30, at p. 12. For more recent work on Meilyr and Pendar, see P.A. Watkins, "The Problem of Pendar: a Lost Abbey in Medieval Senghenydd and the Transformation of the Church in South Wales", unpublished MPhil thesis, University of Wales, Lampeter, 2015, available at <http://repository.uwtsd.ac.uk/647/1/Paul\%2oAnthony\%2oWatkins\%2oMPhil\%2O FINAL\%2OThesis\%20\%281\%29.pdf > (accessed 25 September 2017). 
discovery of a book of prophecies attributed to Myrddin in Nefyn. ${ }^{62}$ Gerald's interest in the work may have contributed to the popularization of Geoffrey in Wales, particularly Gerald's acquaintance with churchmen across Wales. It has been suggested that Gerald's use of "Cambrian" terminology may derive from Geoffrey, since Cambria as a Latinization of Welsh Cymry/Cymru seems to originate with Geoffrey. The popularity of this terminology in texts associated with St Davids would seem to indicate the popularity of Geoffrey's history at St Davids by the later 12th century. ${ }^{63}$ It is clear that Geoffrey's popularity in Wales grew during Gerald's lifetime, and the nature of Gerald's use of Geoffrey is instructive. While he several times casts doubt on the veracity of the work, he nevertheless uses it as a basis for many parts of his account of Welsh history. ${ }^{64}$

Although an unreliable and suspect source, the coherence of the $D G B$ with regard to earlier Welsh historical themes, as well as its all-encompassing nature, meant it was already unavoidable as a source. That this was also the case with more native Latinate writing is apparent from the Life of Gruffudd ap Cynan. This biography of King Gruffudd ap Cynan of Gwynedd was written at some point between 1137 and 1170. Not only does it use "Cambrian" terminology derived ultimately from Geoffrey, an argument among other features for its possible composition at St Davids, but the genealogies of Gruffudd which introduce the history also show the influence of the $D G B \cdot{ }^{65}$

It has been noted above that references within court poetry indicate the influence of Geoffrey's work from around the turn of the 13th century. The earliest surviving manuscripts of Welsh translations of the $D G B$, usually referred to under the collective title Brut y Brenhinedd, date from the mid-13th century and are among the earliest surviving vernacular manuscripts. There were several translations, re-translations, and combinations of previously existing versions throughout the Middle Ages, which created a complex relationship between the different vernacular versions of Geoffrey's history. Overall they show a great degree of faithfulness to the Latin text, but also a willingness

62 J. Crick, "Geoffrey and the Prophetic Tradition", in S. Echard (ed.), The Arthur of Medieval Latin Literature: The Development and Dissemination of the Arthurian Legend in Medieval Latin (Arthurian Literature of the Middle Ages, 6), Cardiff, 2011, pp. 67-82, at p. 69; Gerald of Wales, The Journey through Wales ii.6, ed. Dimock, p. 124.

63 H. Pryce, "British or Welsh? National Identity in Twelfth-Century Wales", EHR 116 (2001), 775-801, at pp. 797-98.

64 J. Crick, "The British Past and the Welsh Future: Gerald of Wales, Geoffrey of Monmouth and Arthur of Britain", Celtica 23 (1999), 6o-75, at pp. 61, 65, 74-75.

65 Life of Gruffudd ap Cynan, ed. P. Russell, Vita Griffini Filii Conani. The Medieval Latin Life of Gruffudd ap Cynan, Cardiff, 2005, pp. 52-55; D. Thornton, "The Genealogy of Gruffudd ap Cynan", in K.L. Maund (ed.), Gruffudd ap Cynan: A Collaborative Biography, Woodbridge, 1996, pp. 79-108, at pp. 82, 86-87. 
to occasionally insert new material or to comment on alternative accounts known to the scribe or translator.

Four of these versions first appear in the 13th century. These are the "Peniarth 44", "Llanstephan 1", "Dingestow", and "Peniarth 21/Peniarth 23" versions. The first manuscripts of the "Cotton Cleopatra" and "Red Book of Hergest" versions belong to the 14th century, and the 15th century sees the first manuscript of the "Peniarth 24" version. ${ }^{66}$ The groundwork for the study of these texts was laid by John Jay Parry and considerably developed by Brynley F. Roberts in a number of important studies. ${ }^{67}$ More recent work by Patrick Sims-Williams has outlined a new approach to understanding the complex and incestuous relationship between these texts. ${ }^{68}$ It is now difficult to see the different versions as entirely independent translations. More than one act

66 These are edited, wholly or partially, in the following: Brut Dingestow, ed. H. Lewis, Llandysul, 1942; B.F. Roberts, "Astudiaeth Destunol o'r Tri Cyfieithiad Cymraeg Cynharaf o Historia regum Britanniae Sieffre o Fynwy, Yngyd ag 'Argraffiad' Beirniadol o Destun Peniarth 44" [A textual study of the three earliest Welsh translations of Geoffrey of Monmouth's Historia regum Britanniae, together with a critical edition of the Peniarth 44 text], unpublished PhD thesis, University of Wales, 1969; Brut y Brenhinedd: Cotton Cleopatra Version, ed. and trans. J.J. Parry, Cambridge, MA, 1937; Text of the Bruts from the Red Book of Hergest, ed. J. Rhŷs and J.G. Evans, Oxford, 189o. Most of the relevant manuscripts are also available from <http://cadair.aber.ac.uk/dspace/handle/216o/5811> and Rhyddiaith Gymraeg 1300-1425 [Welsh prose 1300-1425], ed. D. Luft, P.W. Thomas, and D.M. Smith, Cardiff, 2007-13, <http://www.rhyddiaithganoloesol.caerdydd.ac.uk/> (accessed 3 August 2017).

67 J.J. Parry, "The Welsh Texts of Geoffrey of Monmouth's Historia", Speculum 5:4 (1930), 42431; E. Reiss, "The Welsh Versions of Geoffrey of Monmouth's Historia", wHR 4 (1968/9), 97-127; Roberts, "Astudiaeth Destunol”; Brut y Brenhinedd: Llanstephan MS. 1 Version, ed. B.F. Roberts (Mediaeval and Modern Welsh Series, 5), Dublin, 1971; id., "Ymagweddau at Brut y Brenhinedd hyd 189o" [Attitudes toward Brut y Brenhinedd until 189o], BBCS 24 (1971), 122-38; id., "The Treatment of Personal Names in the Early Welsh Versions of Historia Regum Britanniae", BBCs 25 (1973), 274-89; id., "Fersiwn Dingestow o Brut y Brenhinedd" [The Dingestow version of Brut y Brenhinedd], Bвcs 27 (1976-78), 331-61; id., "The Red Book of Hergest Version of Bruty Brenhinedd", Studia Celtica 12/13 (1977-78), 147-86; id., "Geoffrey of Monmouth, Historia regum Britanniae, and Brut y Brenhinedd", in Bromwich et al. (eds.), The Arthur of the Welsh, pp. 97-116; id., "Ystoriaeu Brenhinedd Ynys Brydeyn: a fourteenth-century Welsh Brut", in J.F. Eska (ed.), Narrative in Celtic Tradition: Essays in Honor of Edgar M. Slotkin (cSANA Yearbook, 8-9), Hamilton, NY, 2011, pp. $215^{-27}$.

68 P. Sims-Williams, Rhai Addasiadau Cymraeg Canol o Sieffre o Fynwy [Some Middle Welsh adaptations of Geoffrey of Monmouth], Aberystwyth, 2o11; id., "The Welsh Versions of Geoffrey of Monmouth's 'History of the Kings of Britain'”, in A. Harlos and N. Harlos (eds.), Adapting Texts and Styles in a Celtic Context: Interdisciplinary Perspectives on Processes of Literary Transfer in the Middle Ages. Studies in Honour of Erich Poppe, Münster, 2016, pp. 53-74. 
of translation is certainly represented within this family of texts, but there was also the combination of existing translations, the adaptation of existing translations with an awareness of the original Latin text, and the addition of other material. Sims-Williams has shown how much work remains to be done on the relationship of these versions to each other and to the Latin manuscripts of the $D G B$, especially in light of our increased understanding of the latter since the work of Julia Crick and Neil Wright. ${ }^{69}$

It can nevertheless be said with certainty that these different Welsh versions of Geoffrey's history demonstrate a keen and lively intellectual interest in his work, which exerted a dominant influence on Welsh ideas of the past. The translations differ in their literary character and overall feel, but all exhibit a conscientious respect for the authority of their Latin source. The Llanstephan 1 Brut shows a cautious and conscientious closeness to the original Latin, but this often results in wooden constructions and literal translations that misrepresent the true sense of the original text. The Dingestow Brut has more of a tendency to condense and shorten the narrative, but it does so effectively and infuses the work with color and liveliness. Peniarth 44 is a more natural translation than Llanstephan 1, but is more direct and less literary than Dingestow, and shows a tendency to condense the narrative which becomes more pronounced as it progresses. ${ }^{70}$ The later versions are also distinctive, with the literary and engaging Cotton Cleopatra version utilizing a wide range of historical texts in an attempt to harmonize Geoffrey's history with native traditions and world history. ${ }^{71}$

There are indications that the Cistercian monasteries of native Wales were important in the production of these texts. The spread of Cistercian monasteries in 12th-century Welsh kingdoms was remarkable. Welsh patronage of these monasteries began in earnest with the assumption of patronage over Strata Florida in Ceredigion by the Lord Rhys in 1165, and the following half-century saw the enthusiastic adoption of the Cistercian order by the other Welsh princes - by the turn of the $13^{\text {th }}$ century every Welsh kingdom contained a

69 N. Wright (ed.) and J. Crick, The Historia regum Britannie of Geoffrey of Monmouth, 5 vols., Cambridge, 1985-91. See also Jaakko Tahkokallio's chapter in this volume.

70 Roberts, "Astudiaeth Destunol", pp. lxxxii-lxxxv, clxvii-clxix, cxc-cxcvii. This tendency to condense is also apparent in the First and Second Variant Versions of the $D G B$, as discussed in Tahkokallio's chapter in this volume. This parallel is interesting given both the association of First Variant manuscripts with Wales, and the fact that Welsh translations could depend both on the Vulgate and First Variant Versions of the $D G B$ - especially Llanstephan 1, which seems to be based on a conflation of both those versions. Roberts, "Geoffrey of Monmouth, Historia regum Britanniae, and Brut y Brenhinedd", p. 111; Brut y Brenhinedd, ed. Roberts, pp. xxxiv-xxxvi.

$71 \quad$ Bruty Brenhinedd, ed. Parry; Roberts, "Ystoriaeu Brenhinedd", pp. 223-26. 
Cistercian monastery. ${ }^{72}$ They often assumed a cultural and political role that made them the successors of older monasteries, and the princes encouraged them in this superseding of earlier institutions. ${ }^{73}$ This gave the order a strong influence on intellectual life in this period: the majority of Welsh vernacular manuscripts between 1250 and 1350 seem to be Cistercian productions. ${ }^{74}$ In these monasteries there was a close connection between Welsh cultural and political concerns and a wider Latin learning which made them likely centers of translation. The involvement of the Cistercians with the politics of their princely patrons suggest that the audience for these translations may have been the lay elite of native Wales, although an interest within the monasteries themselves should not be discounted.

While there are no deliberate, explicit contemporary assessments of Geoffrey's work in the vernacular, the editorial comments, additions, and marginalia present in the Welsh translations reveal something of this. In the Dingestow Brut, for example, the deliberate ambiguity of Geoffrey's account of Arthur's final fate elicits the curt aside "the book says nothing further or clearer about him than that." ${ }^{n 5}$ Certainty rather than elusiveness would have been more to the translator's taste. A response similarly concerned with the accuracy and believability of this important historical narrative may be apparent

72 H. Pryce, "Yr Eglwys yn Oes yr Arglwydd Rhys" [The church in the age of the Lord Rhys], in N.A. Jones and H. Pryce (eds.), Yr Arglwydd Rhys [The Lord Rhys], Cardiff, 1996, pp. 145-77, at pp. $155^{-67}$.

73 J. Bezant, "The Medieval Grants to Strata Florida Abbey: Mapping the Agency of Lordship", in J. Burton and K. Stöber (eds.), Monastic Wales: New Approaches, Cardiff, 2013, pp. 73-87, at pp. 73-75; D.H. Williams, The Welsh Cistercians: written to commemorate the centenary of the death of Stephen William Williams (1837-1899) (The father of Cistercian archaeology in Wales), Leominster, 2001, pp. 272-75. The eclipse of the important clas of Llanbadarn Fawr by the nearby monastery of Strata Florida, and the transfer of the older monastery's chronicle to the newer, is also indicative. Cowley, Monastic Order, pp. 140-41; Bruty Tywysogyon, Peniarth MS. 20, ed. T. Jones (History and Law Series, 6), Cardiff, 1941, p. 154; id., Brut y Tywysogyon: or, The Chronicle of the Princes. Peniarth MS. 20 Version, trans. T. Jones (History and Law Series, 11), Cardiff, 1952, p. xli; J.E. Lloyd, The Welsh Chronicles, The Sir John Rhys Memorial Lecture, British Academy, London, 1928, also printed in Proceedings of the British Academy 14 (1928), 369-91. Pictures derived from Evangelist symbols characteristic of early Insular gospel books in the margins of London, British Library, Cotton Caligula A. iii, a manuscript of the Welsh laws produced at Valle Crucis Abbey, may indicate the inheritance of earlier scribal practices at the monastery. Huws, Medieval Welsh Manuscripts, p. 184.

74 Huws, Medieval Welsh Manuscripts, pp. 52-53.

75 Brut Dingestow, ed. Lewis, p. 185: "Na dyweit y llyuyr amdanav a uo diheuach na hyspyssach na hynny"; B.F. Roberts, "Testunau Hanes Cymraeg Canol” [Middle Welsh historical texts], in G. Bowen (ed.), Y Traddodiad Rhyddiaith yn yr Oesau Canol [The prose tradition in the Middle Ages], Llandysul, 1974, pp. 274-302, at p. 290. 
in the Peniarth 44 translator's decision to omit the $P M$. In so doing he changes the $D G B$ 's comment that Merlin's words reduced the bystanders to amazement to say that he spoke words "difficult for men to believe". ${ }^{76}$ It is tempting to associate this sobriety of approach with translation in a reformed monastery. In another context, such as that of the court poets, it is doubtful whether a prophecy so evocative of earlier Welsh vaticinatory verse would have elicited skepticism.

There were few occasions when Geoffrey's account was in direct conflict with existing tradition, but when there were clear differences, they could be pointed out, as in the case of the parentage of Gwalchmai/Walwanus. Geoffrey's Walwanus is said to be the son of Anna, Arthur's sister, but in Welsh tradition his equivalent Gwalchmai was given the matronymic epithet fab Gwyar, "son of Gwyar". This conflict was resolved in several ways in the Welsh translations. Llanstephan 1 seems to be signaling uncertainty when it relates that Gwalchmai's mother was Anna "according to the truth of the Historia".77 Peniarth 44 neatly solves the problem by noting that Anna was also called Gwyar, whereas Dingestow keeps Geoffrey's account of Walwanus's parentage but on subsequent mentions calls the character Gwalchmai fab Gwyar, creating in effect two characters. ${ }^{78}$ These issues arose in Latin as well as in Welsh. Dublin, Trinity College, 515 (E.5.12) is a manuscript from around 1300 containing the Trojan history of pseudo-Dares followed by the $D G B$, with marginal notes on the latter in Welsh. It was probably produced at a Welsh Cistercian monastery. The marginal comments relate to the parentage of Walwanus, giving his mother as Goear, as well as a note on Severus's wall also derived from Brut y Brenhinedd. ${ }^{79}$ These notes demonstrate the close interplay between Latin and vernacular responses to Geoffrey's work in medieval Wales.

Another Latin manuscript which also indicates a Latinate Welsh response to Geoffrey's history is Cardiff, Central Library, 2.611, dating from around the turn of the 14th century and containing a distinct combination of the vulgate and First Variant versions. ${ }^{80}$ The compiler of this manuscript completed a partial

76 Roberts, “Testunau Hanes”, p. 290: “anhavd kan dynyadon ev credv”; $D G B$, vii.118.1-2.

77 Cardiff, Central Library, 1.363, fol. 14or: "herwyd gwyryoned er hystorya". This part of the "Llanstephan 1" version survives in Cardiff 1.363. For a transcription, see Rhyddiaith Gymraeg 1300-1425, ed. Luft et al., <http://www.rhyddiaithganoloesol.caerdydd.ac.uk/cy/ ms-page.php?ms=Crd1363\&page=140r $>($ accessed 14 July 2017$)$.

78 Roberts, "Geoffrey of Monmouth, Historia regum Britanniae, and Bruty Brenhinedd", p. 113.

79 First Variant Version, ed. Wright, p. lxxxii; B.F. Roberts, "Glosau Cymraeg Historia Regum Britanniae Dulyn, Coleg y Drindod, llsgr. 515 (E.5.12)" [Welsh glosses on the Historia Regum Britanniae in Dublin, Trinity College, manuscript 515 (E.5.12)], Studia Celtica 37 (2003), $75^{-8}$ o.

8o Geoffrey of Monmouth, De gestis Britonum, ed. J. Hammer, Geoffrey of Monmouth. Historia regum Britanniae. A variant version edited from manuscripts, Cambridge, MA, 1951, pp. 8, 
copy of the vulgate version of the $D G B$ using another, more distinctive version of the history which was itself a conflation of the First Variant and the vulgate. This latter version was produced by one brother Madog of Edeirnion, his authorship stated in 26 lines of Latin verse which precede the text. ${ }^{81}$ This poem combines praise of the deeds of the Britons with admiring words for Geoffrey of Monmouth. The response of Madog of Edeirnion to this history was one of creative compilation and verse composition. He saw Geoffrey as an author whose account celebrated the glorious history of the Welsh race. In the 13th century, Madog's response indicates the acceptance of the $D G B$ as an account of the Welsh past which is to be celebrated and popularized, and in which he emphasized the martial prowess of the Britons rather than the centrality of figures such as Arthur. For Madog, at least, the $D G B$ made unproblematic reading for a contemporary Welsh audience. ${ }^{82}$

It has been suggested that Frater Madocus Edeirnianensis is to be identified with Madog ap Gwallter, the author of three Middle Welsh religious poems who probably flourished around $125{ }^{\circ} .{ }^{83}$ The reasons for connecting the two are a perceived similarity in date, since Madog of Edeirnion compiled his version of Geoffrey's history at some point between $c .1200$ and c.130o, and Madog ap Gwallter's supposed birthplace of Llanfihangel Glyn Myfyr, which, though actually in Dinmael, was often misrepresented as being in neighboring Edeirnion. ${ }^{84}$ The link between Madog ap Gwallter and Madog of Edeirnion is a weak one, and the question of the latter's identity is best dealt with separately.

Given Madog of Edeirnion's active and lively engagement with Galfridian material, it may be that he belonged to the Cistercian order which was so prominent in the production of manuscripts of Geoffrey's work both in Latin and the vernacular. Valle Crucis is the closest Cistercian house to Edeirnion, in the neighboring cwmwd of Iâl, and this is also the house whose patrons were the

12-19; D.N. Dumville, "The Origin of the C-Text of the Variant Version of the Historia regum Britannie", ввCS 26 (1974-76), 315-22; First Variant Version, ed. Wright, pp. lxxix-lxxx.

81 First Variant Version, ed. Wright, p. lxxx.

82 J. Byron Smith, "Feasting on the Past".

83 The only direct indication of date is a later note by John Davies of Mallwyd, which gives him a floruit of c.1250; I. Williams, "Cyfeiriad at y Brawd Fadawg ap Gwallter?" [A reference to Brother Madog ap Gwallter?], Bвсs 4 (1928), 133-34; Madog ap Gwallter, Opus, ed. R.M. Andrews, "Gwaith Madog ap Gwallter" [The work of Madog ap Gwallter], in R.M. Andrews et al. (eds.), Gwaith Bleddyn Fardd a Beirdd Eraill Ail Hanner y Drydedd Ganrif ar Ddeg [The work of Bleddyn Fardd and other poets of the second half of the 13th century] (Cyfres Beirdd y Tywysogion, 7), Cardiff, 1996, pp. 345-92.

84 D.M. Lloyd, "Madog ap Gwallter", in J.E. Lloyd, R.T. Jenkins, and W.L. Davies (eds.), $Y$ Bywgraffiadur Cymreig Hyd 1940 [Welsh biography up to 1940], London, 1953, pp. 571-72. There are numerous Llanfihangels in Wales, none of them actually within Edeirnion. 
rulers of Powys Fadog, in which Edeirnion lay. This monastery was active in the production of vernacular historical manuscripts, with two of the three earliest manuscripts of Bruty Brenhinedd probably produced there in the 13th century. The earliest manuscript of the Cotton Cleopatra version of Brut y Brenhinedd was also produced there around $1330 .{ }^{85}$ There is a variant reading in Madog's Latin text which is also present in several versions of Bruty Brenhinedd, including the Cotton Cleopatra version. ${ }^{86}$ Valle Crucis would therefore appear a likely contender for Madog's place of writing. Two monks of Valle Crucis are known to have been called Madog. One was abbot between 1276-84, and another is noted as prior in 1234 and as abbot in $1254{ }^{87}$ Regardless of whether either is identical to Madog of Edeirnion, the importance of this monastery as a center of historical production as well as its proximity to Edeirnion makes it possible that he is to be associated with Valle Crucis.

Madog of Edeirnion's response to the history demonstrates its acceptance as a key element of the Welsh past. There are numerous features in the vernacular translations which also demonstrate a willingness to relate Galfridian history to wider historical traditions as well as a cautious acceptance of this account as a key part of that tradition. For example, the Llanstephan 1 version of Brut y Brenhinedd contains numerous small additions which show an attempt to harmonize parts of the history with other texts. These include one reference to a triad and the quotation of another triad. ${ }^{88}$ The content if not the exact narrative of Geoffrey's history could be harmonized with existing traditions fairly easily. For example, it was a natural step for a translator, seeing Geoffrey's Urianus of Mureif, to equate him with the historical/legendary northern hero Urien Rheged and subsequently to equate Geoffrey's Mureif with the kingdom of Rheged. ${ }^{89}$ Geoffrey clearly knew enough of Urien's place in Welsh tradition to give him a northern location and have him succeeded by his son Owain, and the Welsh translators could naturally expand on these details by correcting the name of his kingdom to Rheged and by naming Urien's own father as Cynfarch, as attested in Welsh sources. ${ }^{90}$

The most notable and substantial addition to the vernacular translations of Geoffrey is the prose tale Lludd and Llefelys. This addition first appears in the Llanstephan 1 version but is also present in most subsequent versions. Into

\footnotetext{
85 Roberts, “Ystoriaeu Brenhinedd", p. 222.

86 J. Byron Smith, "Feasting on the Past".

87 D.H. Williams, "Fasti Cistercienses Cambrenses", вBCS 24 (1971), 181-229, at p. 206.

88 Brut y Brenhinedd, ed. Roberts, p. xxxiii; Trioedd, ed. and trans. Bromwich, pp. 81-89, $153-55$.

$89 \quad D G B$, ix.152.201-08, ix.156.329; Brut Dingestow, ed. Lewis, pp. 152-53, 158; Trioedd, ed. and trans. Bromwich, pp. 508-12. 
Geoffrey's account of Lud son of Heli, the translator inserts the story of Lludd fab Beli and his brother Llefelys, the latter having no Latin equivalent. It is a story of supernatural oppressions or gormesoedd, which partially provides a back-story to the discovery of dragons by Merlin and Vortigern later in the history. The story seems to be independent of the $D G B$, with the brothers mentioned in a poem of Llywelyn Fardd which may date to the third quarter of the 12th century. ${ }^{91}$ It has been said that the tale "belongs, in origin, to the same pseudo-historical traditions as [the] Triads", and what is again apparent here is the reconciliation of Geoffrey's account with historical traditions with which it was thematically broadly consistent but which differed in many details. ${ }^{92}$

The nature of the interaction between more traditional learning and the new influence of Geoffrey's history is indicated in the way the translator introduces the subject of Llefelys. He narrates the Galfridian account of Beli's three sons, then adds, "as some of the cyfarwyddiaid say, he had a fourth son, Llefelys", with cyfarwyddiaid here referring to a class of professional storyteller. ${ }^{93}$ Brynley Roberts notes that, although Lludd and Llefelys derives from such tales, its written style is entirely consistent with the translated, historical

$91 \quad$ A difficulty in dating this poem lies in the fact that the date range of poems ascribed to a Llywelyn Fardd means there must have been at least two poets of this name, perhaps three. The poem in question, written in praise of Llywelyn ab Iorwerth (active career 1187-1240), could be ascribed either to an earlier or a later Llywelyn Fardd or, as Nerys Ann Jones suggests, the second of three similarly-named bards. Brynley Roberts ascribes it to an elder Llywelyn Fardd, and therefore to around 1187-1200, whereas the editors of Cyfres Beirdd $y$ Tywysogion ascribe it to the younger poet. In the latter case, Catherine McKenna suggests a date of around 1216 for the poem to Llywelyn ab Iorwerth, which may mean that the reference in this poem to Lludd and Llefelys post-dates the inclusion of the tale in the Welsh Brut translations of Geoffrey's work. She also, however, acknowledges a reasonable alternative date of $c .1187$, which would imply authorship by the elder Llywelyn Fardd. I prefer to read the poem as one sung for Llywelyn ab Iorwerth very early in his career, as suggested by Nerys Ann Jones. Cyfranc Lludd and Llefelys, ed. B.F. Roberts (Mediaeval and Modern Welsh Series, 7), Dublin, 1975, p. xx; Llywelyn Fardd I, Opus, ed. C. McKenna, "Gwaith Llywelyn Fardd I" [The work of Llywelyn Fardd I], in M.E. Owens et al. (eds.), Gwaith Llywelyn Fardd I ac Eraill o Feirdd y Ddeuddegfed Ganrif [The work of Llywelyn Fardd I and other poets of the 12th century] (Cyfres Beirdd y Tywysogion, 2), Cardiff, 1994, pp. 1-100, at p. 3; Llywelyn Fardd II, Opus, ed. C. McKenna, "Gwaith Llywelyn Fardd II" [The work of Llywelyn Fardd II], in N.G. Costigan et al. (eds.), Gwaith Dafydd Benfras ac Eraill o Feirdd Hanner Cyntafy Drydedd Ganrif ar Ddeg [The work of Dafydd Benfras and other poets of the first half of the 13th century] (Cyfres Beirdd y Tywysogion, 6), Cardiff, 1995, pp. 99-157, at pp. 106-13; N.A. Jones, “Llywelyn Fardd I, II, III?” Llên Cymru 29 (2006), 1-12, esp. pp. 7, 10-11.

$92 \quad$ Lludd and Llefelys, ed. Roberts, pp. xvii, xx.

93 Cardiff 1.363, fol. 46r: "megys y dyweyt rey o'r kyuarwydyeyt, petweryd mab a wu ydaw Llevelys." See Lludd and Llefelys, ed. Roberts, p. xv. 
style of the rest of Bruty Brenhinedd. The author was not, therefore, writing in the style of the cyfarwyddiaid, but rather adopting a story from that tradition and adapting it to suit the style of the translations of the $D G B$. He is more likely to have been an ecclesiastic with a learned Latin background, similar perhaps to Madog of Edeirnion, rather than a court poet or one of the cyfarwyddiaid. ${ }^{94}$ Lludd and Llefelys indicates a dynamic interplay between texts, languages, and genres which characterizes the response to Geoffrey in Wales. The $D G B$ is changed by translation and by the addition of a native prose tale, but the style of this cyfarwyddyd itself is changed to the sparer, translated Welsh prose of Bruty Brenhinedd.

The dialogue between Galfridian and other native traditions is apparent in other sources. When the Peniarth 44 translator noted of Severus's wall hvnnv a eylw e beyrd gweyth Escavl Vynyd, "this the poets call the work (gweyth) of Escawl Mountain", he was misunderstanding poetic traditions concerning the 7th-century king Cadwallon's battle of Gweyth Canyscawl, with gweyth here signifying "battle. ${ }^{95}$ This same mistake was made by the author of the Welsh marginalia in TCD $515 .{ }^{96}$ This dialogue is apparent beyond the texts and translations of Geoffrey, as in the genealogy of Llywelyn ap Gruffudd in Aberystwyth, National Library of Wales, 3036B, previously known as Mostyn 117. Here, a discrepancy in the parentage of the grandson of Maelgwn Gwynedd is noted, with one account being herwyd dull y beird, "according to the way of the poets". The other option is given herwyd yr Istoria, "according to the Historia", with Maelgwn further described as the fourth king over the island of Britain after Arthur. ${ }^{97}$ We know from Gerald of Wales that the Welsh poets kept their own written genealogies, and this genealogy gives a further indication that in Gwynedd by the second half of the 13th century, the discrepancies between these accounts and Galfridian pseudo-history were being acknowledged and reconciled. That this should have happened in the genealogy of Llywelyn ap Gruffudd of Gwynedd, who had come to dominate native Wales, indicates the political significance of this history. Llywelyn's attempts to transform his hegemony over the other Welsh princes into a more consistent and lasting authority depended on the English king recognizing him as Prince of Wales, who exerted authority over the other native princes despite himself paying homage and fealty to the king of England. ${ }^{98}$ In this respect, it is probably significant that by

$94 \quad$ Lludd and Llefelys, ed. Roberts, p. xxviii.

95 For the references to this battle in Historia Brittonum and Annales Cambriae, see Faral, $L L A$, vol. 3, pp. 43,46 .

96 Roberts, “Testunau Hanes”, pp. 291-92; First Variant Version, ed. Wright, p. lxxxii.

97 Early Welsh Genealogical Tracts, ed. P.C. Bartrum, Cardiff, 1966, pp. 38-39.

98 J. Beverley Smith, Llywelyn ap Gruffudd, pp. 20-27, 335-37. 
this point Llywelyn's genealogy is traced through Camber, son of Brutus, rather than Locrinus, as was the case in the Galfridian-influenced Gwynedd genealogies in the Life of Gruffudd ap Cynan. ${ }^{99}$ Claiming descent from Locrinus made Llywelyn a descendant of the kings of Britain, who lost their authority after the death of Cadwallon. Claiming descent from Camber, however, offered a model of independent rule subject to the crown of London which was supported by the authority of a history accepted both in Wales and in England. ${ }^{100}$

The Welsh and Latin versions of Geoffrey's history produced in Wales demonstrate a remarkable closeness in their response, as well as indicating that the class of men who were involved in this translation and copying were not lay poets and cyfarwyddiaid but rather monks and ecclesiastics. The historical work undertaken at the monasteries of native Wales, particularly the Cistercian monasteries affiliated to Whitland, had a strong role in the ultimate assimilation of Geoffrey's work into Welsh historical tradition and its acceptance as one of the central texts of the Welsh past. This came about through the copying and translation of Geoffrey's work and its reconciliation with existing traditions, but also through the association of the Galfridian past with the pre-existing and independent compilation of monastic chronicles in Latin.

The chronicles of native Wales can be divided into vernacular and Latin annals, but again, as with Galfridian texts, the linguistic division exposes a fundamental similarity, with both being different reflexes of the same activity. Latin annals had been kept at Welsh monasteries since at least the mid-8th century, most notably at St Davids. ${ }^{101}$ The new monasteries of 12th-century Wales began to keep chronicles fairly soon after their foundation, and in some cases incorporated the annals of older churches, most notably those of St Davids and Llanbadarn Fawr, in their own chronicles. ${ }^{102}$ Our first examples of vernacular chronicles occur in 14th-century manuscripts, but they may have been

99 D.E. Thornton, "A Neglected Genealogy of Llywelyn ap Gruffudd", cMcs 23 (1992), 9-23, at pp. $18-20$.

100 My thanks to Ben Guy for discussing this genealogy and indicating the significance of its use of Geoffrey's history in a conference paper and personal correspondence; B. Guy, "'O herwyd yr Istoria': The Appropriation of Geoffrey of Monmouth's British History in Medieval Welsh Genealogy", unpublished paper delivered at the International Medieval Congress, University of Leeds, 8 July 2015.

101 K. Hughes, Celtic Britain in the Early Middle Ages, Studies in Scottish and Welsh Sources, ed. D.N. Dumville (Studies in Celtic History, 2), Woodbridge, 1980, pp. 68-69, 85-88, 100; B. Guy, "The Origins of the Compilation of Welsh Historical Texts in Harley 3859 ", Studia Celtica 49 (2015), 21-56, at pp. 25-45.

102 Hughes, Celtic Britain, pp. 73-85, especially the summary on p. 85; O.W. Jones, "Brut $y$ Tywysogion", pp. $215^{-16 .}$ 
translated earlier, in the 13th century. ${ }^{103}$ They are almost all derived from Latin originals, and their translation was closely bound with the translation and compilation of the vernacular versions of Geoffrey's history. Much of their material derives from the chronicle of the Cistercian monastery of Strata Florida, a chronicle which also influenced some of the surviving Latin chronicles but which does not survive in an untranslated or unabridged guise. ${ }^{104}$

The influence of Galfridian historical ideas on these chronicles is great in terms of their framing and presentation, but far less so in the case of their actual narrative content. For example, both the Breviate and Cottonian chronicles, two of the Latin annals commonly referred to as Annales Cambriae, place their narratives in a framework of world-history which derives substantial material from the $D G B \cdot{ }^{105}$ The vernacular chronicles, collectively termed Brut $y$ Tywysogyon, themselves begin with the death of King Cadwaladr, and from their openings are quite clearly conceived of as continuations of a British/ Welsh narrative in which Geoffrey's history had assumed a central part. ${ }^{106}$ However, the influence of Geoffrey's work, and the frequency of Galfridian references, in the body of the narrative of both the Welsh and Latin chronicles is

103 The earliest Welsh vernacular chronicle seems to be the short text O Oes Gwrtheyrn, for which see O.W.Jones, "O Oes Gwrtheyrn: a Medieval Welsh Chronicle", in B. Guy, G. Henley, O.W. Jones, and R.L. Thomas (eds.), The Chronicles of Medieval Wales and the March: New Contexts, Studies and Texts (Medieval Texts and Cultures of Northern Europe), Turnhout, forthcoming.

104 The different chronicles and editions are as follows. Latin: Harleian chronicle (A-text), ed. Faral, $L L A$, vol. 3, pp. 44-5o; Breviate chronicle (B-text), ed. H. Gough-Cooper, Annales Cambriae: A, B and C in Parallel, from St Patrick to AD 954, 2016, <http://croniclau.bangor.ac.uk/editions.php.en> (accessed 4 August 2017); Cottonian chronicle (C-text), ed. H. Gough-Cooper, Annales Cambriae: A, B and C in Parallel, from St Patrick to AD 954, 2016, <http://croniclau.bangor.ac.uk/editions.php.en> (accessed 4 August 2017); Cronica de Wallia, ed. T. Jones, "'Cronica de Wallia' and other documents from Exeter Cathedral Library MS. 3514”, ввCS 12 (1946), 27-44. Welsh-language: Brut y Tywysogyon, Peniarth MS. 2o, ed. Jones; Bruty Tywysogyon: or, The Chronicle of the Princes. Peniarth MS. 20 , trans. Jones; Brut y Tywysogyon: or, The Chronicle of the Princes. Red Book of Hergest Version, ed. and trans. T. Jones (History and Law Series, 16), Cardiff, 1955; Brenhinedd y Saesson: or, The Kings of the Saxons: BM Cotton MS. Cleopatra Bv and the Black Book of Basingwerk, NLW MS. 7006, ed. and trans. T. Jones (History and Law Series, 25), Cardiff, 1971. For the Latin chronicles, the terminology "Breviate" and "Cottonian" chronicles is to be preferred to the more established terminology which describes them as the "B" and " $\mathrm{C}$ " versions of Annales Cambriae, since it clarifies the fact that these two are very different chronicles.

105 C. Brett, "The Prefaces of Two Late Thirteenth-Century Welsh Latin Chronicles", ввсs 35 (1988), 63-73.

106 Brut y Tywysogyon: or, The Chronicle of the Princes, Peniarth MS. 20, trans. Jones, pp. xxxviii-xxxix. 
negligible, more often derived from an intermediary source than inserted as part the chronicler's historiographical vision.

For example, a reference to the prophecies of Myrddin present in all three versions of the Welsh chronicles Bruty Tywysogyon/Brenhinedd $y$ Saesson for 1279 seems to be due to the influence of English chronicling, being noted in the chronicle of William Rishanger. ${ }^{107}$ An earlier instance of a similar reference to the $P M$ can be found in the Latin Breviate chronicle's entry for 1214, again with reference to English affairs. ${ }^{108}$ Whereas the vernacular Peniarth 20 Bruty Tywysogyon mentions Camber, Locrinus, and Albanactus at the death of the Lord Rhys of Deheubarth in 1197, it does so in quoting a contemporary Latin poem lamenting his death. ${ }^{109}$ While the figures of Galfridian history were by this point appropriate figures of comparison for a rhetorical lament, as they had become in the case of vernacular court poetry, they had no real place in the main body of these monastic chronicles.

In fact, when allusions are present in the chronicles they place them in the wider framework of Christian history rather than showing a debt to Geoffrey's work. References to the books of Maccabees provide such an example. The first book is frequently referred to in the Latin Life of Gruffudd ap Cynan, where the characterization of Gruffudd as equivalent to Judas Maccabaeus and Hugh of Chester as Antiochus is sustained throughout much of the text. ${ }^{110}$ Twice in the Breviate chronicle the Welsh are compared to the Maccabees, both times in the context of resistance to English armies. ${ }^{111}$ The high adventure and warlike character of the account of the revolt of the Maccabees made it popular in general in the Middle Ages as a model for martial prowess, but in a Welsh context there were more specific parallels. ${ }^{112}$ The revolt was against a powerful kingdom to free a nation from foreign domination, the resurgent rebels having

107 William Rishanger was a monk of St Albans and a continuator of Matthew Paris's Chronica majora from 1259 to 1307. A. Gransden, Historical Writing in England, II: c. 1307 to the Early Sixteenth Century, London, 1982, pp. 4-5; Brut y Tywysogyon, Peniarth MS. 20, ed. Jones, p. 226; Brut y Tywysogyon: or, The Chronicle of the Princes. Red Book of Hergest Version, ed. and trans. Jones, p. 268; Brenhinedd y Saesson, ed. and trans. Jones, p. 256; L. Keeler, Geoffrey of Monmouth and the Late Latin Chroniclers, 1300-1500, Berkeley, 1946, pp. 50, 102; William Rishanger, Chronicle, ed. H.T. Riley, Willelmi Rishanger, quondam monachi S. Albani, et quorundam anonymorum, chronica et annales, regnantibus Henrico tertio et Edwardo primo, London, 1865, pp. 1-23o, at p. 94.

108 Breviate chronicle, ed. Gough-Cooper, s.a. $1236=1214$.

109 Bruty Tywysogyon, Peniarth MS. 20, ed. Jones, p. 140.

110 Life of Gruffudd, ed. Russell, pp. 48, 219.

111 Breviate chronicle, ed. Gough-Cooper, s.a. 1267=1246, 1277=1256; J. Beverley Smith, Ymwybod â Hanes yng Nghymru, p. 8.

112 M. Keen, Chivalry, Bath, 1984, pp. 119-22. 
to cope with internal betrayal as well as overwhelming odds on the side of the aggressors. ${ }^{113}$ For monastic chroniclers intimately involved in the struggle for Welsh independence, this may have been a more illuminating and inspiring allusion than Geoffrey's story of British loss and decline, albeit with a promise of eventual redemption.

Galfridian influence on the structure and setting of chronicles increased during the course of the 13th century. By the turn of this century the authority of Geoffrey's work was accepted in principle by Gerald of Wales, and its influence on vernacular poetry is perceptible from around 1200. The setting of the Latin Breviate and Cottonian chronicles within a framework of worldhistory under considerable Galfridian influence must be dated after 1202 . The world-history material they both draw on was from St Davids, but whereas the Cottonian chronicle was combined with this material at St Davids itself, in the case of the Breviate this was probably undertaken at a Welsh Cistercian monastery. That both chronicles were joined to this material independently is indicative of a broader impulse for the acceptance of the Galfridian past. ${ }^{114}$ In the vernacular, the short chronicle O Oes Gwrtheyrn ("From the Age of Vortigern") was also framed in Galfridian terms around 1212. ${ }^{115}$ A grander example of such an impulse is Exeter, Cathedral Library, 3514, a manuscript of the late 13th century containing a constructed composite history consisting of Dares Phrygius, the First Variant version of Geoffrey's history, and Henry of Huntingdon's History of the English. ${ }^{116}$ After these texts the manuscript contains the Cronica de Wallia, a Latin chronicle focused on the affairs of the princes of Deheubarth, which indicates that the Exeter manuscript is probably a product of the Cistercian monastery of Whitland. ${ }^{117}$ The manuscript illustrates the role of Geoffrey's work in placing Welsh history in a wider chronological and historiographical tradition - it is how the Welsh material is placed in both a British and an English context. ${ }^{118}$ In the 13th century, when conflict between Welsh

113 Life of Gruffudd, ed. Russell, p. 48. For a comparable case of Maccabees being seen as a parallel for contemporary military conflict on the 1oth-century German frontier, see J. Dunbabin, "The Maccabees as Exemplars in the Tenth and Eleventh Centuries", in K. Walsh and D. Greenway (eds.), The Bible in the Medieval World: Essays in Memory of Beryl Smalley (Studies in Church History, Subsidia 4), Oxford, 1985, pp. 31-41.

114 Brett, "The Prefaces", pp. 70, 72.

115 O.W. Jones, "O Oes Gwrtheyrn", forthcoming.

116 Crick, $S C$, no. 7 o.

117 J. Beverley Smith, "The 'Cronica de Wallia' and the Dynasty of Dinefwr: a Textual and Historical Study", вBCS 20 (1962-64), 261-82, at pp. 279-82.

118 J. Crick, "The Power and the Glory: Conquest and Cosmology in Edwardian Wales (Exeter, Cathedral Library, 3514)", in O. Da Rold and E. Treharne (eds.), Textual Cultures: Cultural Texts, Cambridge, 2010, pp. 21-42, at pp. 21-25, 30-36. 
rulers and the English crown produced increasing political and cultural polarization, Geoffrey's ambiguous history had come to form part of the historiographical background of Wales. But rather than being a wholesale acceptance of Anglo-Norman historiographical norms, this history was accepted in Wales with careful consideration of existing ideas of the past, and this acceptance was the product of a society divided by imperfect conquest. It was achieved with essentially the same texts but independently at St Davids and Whitland, on the one hand an episcopal seat which became increasingly Anglicized in the 13th century, and on the other a Welsh Cistercian house which assumed a position of authority over the other monasteries of native Wales.

The conception and manuscript setting of the vernacular chronicles are closely related to the situation apparent in Latin manuscripts. In an indirect way, the Exeter manuscript can be seen as a precursor to the vernacular manuscripts of the 14th century which contain Welsh versions of Dares Phrygius (Ystorya Dared) and the DGB (Bruty Brenhinedd), as well as Bruty Tywysogyon. The effect of combining these three works in sequence was to create a continuous historical narrative which related first the Trojan War, then the foundation of Britain by Trojan exiles followed by their loss of sovereignty over the island, and then the subsequent history of these Britons as the Welsh from the $7^{\text {th }}$ century to the 13 th.

The earliest full manuscript of this "Welsh Historical Continuum" (Aberystwyth, National Library of Wales, $3035^{\mathrm{B}}$, previously known as Mostyn 116) dates to the second half of the 14th century. The works contained in this triad of texts can be associated with different parts of Wales. Bruty Tywysogyon in its 13th-century form is a product of Strata Florida in Ceredigion. The "Red Book" version of Brut y Brenhinedd present here was compiled from two 12thcentury versions, one of which first survives in a manuscript (Aberystwyth, National Library of Wales, Llanstephan 1) that was probably produced at another Cistercian house, Valle Crucis in northern Powys, the other of which occurs in manuscripts which can be associated with North Wales (Aberystwyth, National Library of Wales, 5266B, "Brut Dingestow"; Aberystwyth, National Library of Wales, 3036B, previously known as Mostyn 117 ). ${ }^{119}$ However, most of the manuscripts of this version of the complete continuum have a South Welsh provenance. What is clear is that the Welsh Historical Continuum found

119 Huws, Medieval Welsh Manuscripts, pp. 53, 179; id., "The Manuscripts", in T.M. CharlesEdwards, M.E. Owen, and D.B. Walters (eds.), Lawyers and Laymen: Studies in the History of Law Presented to Professor Dafydd Jenkins on his Seventy-Fifth Birthday, Gîyl Ddewi 1986, Cardiff, 1986, pp. 119-36, at pp. 127-30; id., A Repertory of Welsh Manuscripts and Scribes, forthcoming; NLW 5266B (Brut Dingestow), NLW 3036B (Mostyn 117), Llanstephan 1. 
in NLW $3035^{B}$ /Mostyn 116 was the end result of several axes of transmission of historical material which crossed Wales. These were undoubtedly dependent on links between Welsh Cistercian houses, given the fact that most of these manuscripts themselves seem to be products of Cistercian monasteries. In the late 14th century and into the $15^{\text {th }}$, manuscripts of the Red Book version are apparent both in North and South Wales, underlining the importance of these networks in the spread of historical material as well as its composition.

By this point the princes who had founded and patronized these monasteries, and who used their abbots as officials and ambassadors, had vanished as a result of the Edwardian conquest of the late 13th century. The court poets, who had formed one of the intellectual elites of native Wales, had lost their most important sponsors with the disappearance of the princely court as an institution. Welsh poetry nevertheless survived under the patronage of the uchelwyr, the native gentry, and these men were also important as the audience for the Welsh Historical Continuum which established Geoffrey's account as the central narrative of the Welsh past. It is in this context that Hopcyn ap Thomas and his scribe, Hywel Fychan, with whom this chapter opened, read the Philadelphia manuscript and decided that the current conquered state of the Welsh had roots far further back than the 13th-century conquest.

Geoffrey's account was written in the 12th century, when the ambitions and interests of the Anglo-Norman elite and their expansion in Wales created a ready audience for an account of the British past. In the course of the 13th century it became accepted as an essential part of Welsh history, and in the context of a struggle for the maintenance of Welsh political autonomy, it sometimes assumed a political role, whether in Llywelyn ap Gruffudd's claims to descent from Camber or in Edward I's conscious appropriation of these ideas in the wake of his conquest of Gwynedd. Edward's purported discovery of the body of Magnus Maximus at Caernarfon in 1283, and indeed the entire structure of the castle at Caernarfon, with its imperial eagles and banded masonry evocative of Roman construction, was intended to echo and to appropriate the inheritance that the Welsh claimed, under the influence of Geoffrey, as historical equals of the Romans. ${ }^{120}$ This appropriation went hand in hand with

120 R.R. Davies, Conquest, Coexistence and Change: Wales, 1063-1415, Oxford, 1987, p. 360; A.J. Taylor, Welsh Castles of Edward I, Bristol, 1986, pp. 77-79; A. Wheatley, "Caernarfon Castle and its Mythology", in D.M. Williams and J.R. Kenyon (eds.), The Impact of the Edwardian Castles in Wales: the Proceedings of a Conference Held at Bangor University, 7-9 September 2007, Oxford, 2010, pp. 129-39; Flores Historiarum, ed. Luard, vol. 3, p. 59. Flores Historiarum relates the discovery of the grave of Maximus, father of the noble Constantine. Historia Brittonum had earlier referred to a tomb of Constantine there; Historia Brittonum, ed. Faral, LLA, vol. 3, p. 19. 
discouragement, as in June 1284 when Archbishop Peckham issued injunctions for the clergy of the diocese of St Asaph reminding them of their responsibility to reconcile Welsh and English, and specifically warned against Welsh tales of their glorious descent from the Trojans. ${ }^{121}$

The narrative formulated by Geoffrey of Monmouth was given historical and political authority in a Wales where claims of authority were articulated and disputed frequently. Wales itself was a deeply divided country throughout the 12th and 13th centuries, and many of these divisions are apparent in the processes of historiographical dialogue, acceptance, and translation outlined above. Geoffrey, elusive and ambiguous though he is as an author, was himself divided between the Anglo-Norman world for which he wrote, and the Welsh world which provided most of the source material and thematic preoccupations of his history. The response to the $D G B$ in Wales shows the reconciliation and fusion of older Welsh ideas of history to Geoffrey's reformulation of these same ideas.

This response itself indicates both divisions and connections. The production of vernacular court poetry, and closely-related vernacular texts such as Trioedd Ynys Prydein, depended on the context of the Welsh princely courts. The articulation of the Welsh past was here dependent on the patronage of Welsh rulers, their families, officials, and of the wider court, a place of central importance in the articulation of prophecy, lore, history, and "cultural orientation". ${ }^{22}$ The peripatetic nature of the court itself and of the court poets and cyfarwyddiaid who were associated with it extended the influence of their articulation of the past. The acceptance of Geoffrey's history in this context is apparent from the turn of the 13th century in the court poetry, but it is never dominant - rather it simply emerges in such poetry as one of many sources of reference and allusion, one of many ways in which the Welsh past could be viewed.

The Latin evidence indicates a slightly earlier acceptance of Geoffrey's account. The Latin Life of Gruffudd ap Cynan and Gerald of Wales show Geoffrey's influence by the second half of the 12th century. The response of

\footnotetext{
121 G. Williams, The Welsh Church from Conquest to Reformation, 2nd ed., Cardiff, 1976, p. 41; John Peckham, Epistles, ed. C.T. Martin, Registrum Epistolarum Fratris Johannis Peckham, Archiepiscopi Cantuariensis, 3 vols., London, 1882-85, vol. 2, pp. 737-43.

122 Sims-Williams, "Some Functions of Origin Stories", pp. 101-02.
} 
Brother Madog of Edeirnion in the 13th century illustrates his importance by that point, and, along with other manuscript evidence from Cistercian monasteries, shows the key role of reformed monasteries in the articulation of the Welsh past in Galfridian terms. The Cistercian monasteries of native Wales were also important in the establishment of a sequential relationship between Geoffrey's narrative and the chronicle writing undertaken at these institutions, apparent in Latin and later in vernacular manuscripts.

The significant division in terms of the Welsh response to Geoffrey is not a linguistic one, but rather one of genre, as well as of institutions. The Welsh translations of Geoffrey are similar to Welsh Latin manuscripts in terms of their preoccupations and marginal additions, and were probably also the work of monks rather than cyfarwyddiaid. Whereas vernacular court poetry refers to figures of Geoffrey's from around 1200, the same can be said for the Latin lament for Rhys ap Gruffudd which dates to around 1197, similar to vernacular court poetry in terms of genre. ${ }^{123}$ In institutional terms, we should perhaps ascribe a more important role in the popularization of Galfridian history to Cistercian monasteries rather than to the cyfarwyddiaid and court poets, although the acceptance of Geoffrey's account by the latter two is clear in the course of the $13^{\text {th }}$ century.

The role Galfridian history played in the closing years of the struggle between the princes of Gwynedd and the English crown was discussed above. This struggle was the dominant political process of the 13th century in Wales, and resulted in the disappearance of the Welsh princely court as an institution. Whereas the evidence for the 13th century indicates a dynamic process of response, reformulation, and acceptance, it is arguable that the 14th century saw the assumption by Geoffrey's history of a role as the central authority on the Welsh past, best articulated in the "Welsh Historical Continuum" of some vernacular manuscripts. This importance was the product of the historiographical activity of the 13th century, but also perhaps of the disappearance of the Welsh court which provided an alternative center of cultural orientation to the reformed monasteries. The assumption of a leading cultural role by Cistercian monasteries in the wake of the disappearance of the princely courts is perhaps best exemplified by the production of the Hendregadredd manuscript, a comprehensive collection of vernacular court poetry, at Strata Florida in the

123 For the Latin poetry to the Lord Rhys, see "Y Canu Lladin er Cof am yr Arglwydd Rhys" [The Latin poetry commemorating the Lord Rhys], ed. H. Pryce, in Jones and Pryce (eds.), Yr Arglwydd Rhys, pp. 212-23. For a recent discussion noting the similarity between this and vernacular poetry, see P. Russell, “'Go and Look in the Latin Books': Latin and the Vernacular in Medieval Wales", in R. Ashdowne and C. White (eds.), Latin in Medieval Britain (Proceedings of the British Academy, 206), London, 2017, pp. 213-46. 
years after $1282 .{ }^{124}$ These abbeys were culturally and politically important before the conquest, but whereas the loss of the princes and their court at the conquest decreased their political importance, they increased their centrality in cultural terms. They did so in association with a lay elite who had survived the conquest and who were now the chief sponsors of the Welsh poets. Their association with Cistercian monasteries is clear from instances such as the ties between Strata Florida and the family of Parcrhydderch, and the rich corpus of inscribed gravestones which commemorates the attachment of such families to Valle Crucis in the first half of the 14th century. ${ }^{125}$

By the time of Hywel Fychan's scribal colophon, Galfridian history was part of an authoritative narrative of Welsh history which provided ideological justification for Glyn Dŵr's revolt. Even with the failure of this revolt, Geoffrey's legacy maintained this role. Indeed, its emphasis on the British dimension of the Welsh past, though founded on impeccable native tradition, was useful in a situation when the Welsh now needed to reconcile themselves to operating within an English dimension. It was especially useful, and especially misleading, in interpreting the victory of Henry VII in 1485 as a return of British sovereignty to the island, giving the Welsh elite historical and political justification for their role in the Tudor state. ${ }^{126}$ The debate over the veracity of Geoffrey's history in the 16th century exposes the continuing importance of this narrative to national self-definition. ${ }^{127}$ And whereas Geoffrey was largely no longer considered a reliable historical source in England by 16oo, in Wales the debate went on, so tied was the work to ideas of national pride. This debate continued into the 19th century, and it was only then that the hold of Galfridian history over the Welsh historical consciousness, along with the manuscript tradition of copying and recopying the Welsh translations, was broken. ${ }^{28}$

124 Llawysgrif Hendregadredd [The Hendregadredd manuscript], ed. J. Morris-Jones and T.H. Parry-Williams, Cardiff, 1933; Huws, Medieval Welsh Manuscripts, pp. 193-226.

125 Huws, Medieval Welsh Manuscripts, pp. 247-54; C.A. Gresham, Medieval Stone Carving in North Wales, Cardiff, 1968, pp. 79-84, 89, 94-96, 113-16, 137-41, 182-88.

126 Sims-Williams, "Some Functions of Origin Stories", pp. 110-11.

127 See for example David Powel's careful distinction between the activities of Welsh kings and princes in the past and the contented situation of Wales in the present under the Tudor monarchs, in his edition of Humphrey Lhuyd's Cronica Walliae. A.O.H. Jarman, "Y Ddadl Ynghylch Sieffre o Fynwy" [The debate surrounding Geoffrey of Monmouth], Llên Cymru 2 (1952), 1-18, at pp. 11, 13-14; The historie of Cambria, now called Wales, ed. D. Powel, London, 1584 .

128 Roberts, "Ymagweddau”, pp. 123, 126, 135-38. I wish to thank Huw Pryce, Ben Guy, Georgia Henley, and Joshua Byron Smith for wise and valuable comments on drafts of this chapter. 